\title{
Infection by Trypanosoma spp. in Platydoras armatulus (Siluriformes, Doradidae), in Southwestern Amazon, Brazil
}

Lucena Rocha Virgilio ( $\nabla$ lurubita@gmail.com )

Universidade Federal do Acre https://orcid.org/0000-0002-8782-1009

Gabriele Oliveira Texeira

Federal University of Acre: Universidade Federal do Acre

Henrique Paulo Silva De Melo

Federal University of Acre: Universidade Federal do Acre

Sérgio Luiz Prolo Junior

Federal University of Acre: Universidade Federal do Acre

Ricardo Massato Takemoto

State University of Maring: Universidade Estadual de Maringa

Luís Marcelo Aranh Camargo

University of São Paulo Institute of Biomedical Sciences: Universidade de Sao Paulo Instituto de

Ciencias Biomedicas

Dionatas Ulisses Meneguetti

Federal University of Acre: Universidade Federal do Acre

\section{Research Article}

Keywords: Acre, Fishes, Parasitology, Hemoparasite

Posted Date: March 31st, 2021

DOl: https://doi.org/10.21203/rs.3.rs-355103/v1

License: (c) (1) This work is licensed under a Creative Commons Attribution 4.0 International License. Read Full License 


\section{Abstract}

Trypanosoma is a hemoflagellate capable of infecting a wide variety of invertebrates and vertebrates, such as Neotropical freshwater fish. Thus, the present study described and morphologically compared Trypanosoma sp., found in Platydoras armatulus, Valenciennes, 1840, in southwestern Amazon. A sampling of fish specimens was carried out in a river located in Guajará, Amazonas, Brazil. Fish blood samples were collected through a cardiac puncture. Thus, smears were made for quantification, morphometric measurements, and morphotyping of trypanosomes found. Prevalence, mean abundance, and intensity of parasitism were estimated in the specimens of parasitized fish. Five fish specimens were collected, showing a $100 \%$ prevalence of parasites in the host. We found two Trypanosoma morphotypes, A and B, in which A had the highest infection intensity in host specimens. Thus, the present study showed the first report of Trypanosoma spp. in P. armatulus, besides the probability of two parasitic morphospecies in the blood of these fish specimens.

\section{Introduction}

Blood parasites of the genus Trypanosoma occur in diverse invertebrates (Meneguetti et al. 2014) and vertebrates (Molyneux 1983), such as Neotropical freshwater fish. Most of these hemoparasites are heterogeneous, i.e., they involve two hosts to complete their life cycle (Molina et al. 2016). Trypanosomes in the blood of infected fish undergo many morphological transformations (amastigote, spheromastigote, epimastigote, and trypomastigote) until they are consumed by leech species, which ingest the infected blood. These flagellates then begin to divide in the leech stomach (Lom and Dykova 1992; Eiras 1994, Eiras et al. 2008; Corrêa et al. 2016).

Trypanosoma infection can cause anemia in fish (Khan 1985) and is directly related to parasitemia (Woo 2006, Ahmed et al. 2011). Besides, some studies have reported several changes in vital organs of infected fish, and in some cases, anorexia associated with high infection by trypanosomes (Dyková and Lom 1979; Islam and Woo 1991). However, although some Trypanosoma species cause mortality and morbidity of vertebrate hosts (Ardelli and Woo 1998), studies have recorded persistence of infection with host survival, which may indicate parasite-host coevolution, with a delicate balance between the mechanisms of parasite evasion and fish immune system (Overath et al. 1999; Wiegertjes and Forlenza 2010). Thus, studies with fish trypanosomes are important not only for knowing potential ichthyofauna pathogens but helping understand these parasite adaptations to survive in different hosts and different geographical regions (Kelly et al. 2014), as found in mammalian trypanosomes (Echodu et al. 2015, Greif et al. 2015).

In Brazil, there are approximately 60 Trypanosoma species described infecting diverse freshwater and saltwater fish families (Eiras et al. 2012). For the family Doradidae, Trypanosoma spp. has been found in Pterodoras granulosus (Albuquerque et al. 1996), Trachydoras paraguayensis (Eiras 1991), Rhinodoras dorbignyi (Fonseca e Vaz 1928), Franciscodoras marmoratus (Fonseca 1935), and Corydoras sp. (Eiras et al. 2012). However, there was no study of Trypanosoma hemoparasitizing Platydoras armatulus 
Valenciennes, 1840. Thus, the present study aims to report, for the first time, the occurrence of Trypanosoma spp. in P. armatuluse and morphologically compare two morphotypes of these hemoparasites found in this fish species.

\section{Material And Methods}

\section{Study area}

The fish were collected (authorization from the Brazilian Institute of Environment and Renewable Natural Resources No. 59642-2/2019) in the Ipixuna River ( $7^{\circ} 17^{\prime} 13^{\prime \prime} S 72^{\circ} 36^{\prime} 49^{\prime \prime}$ W), a tributary of the Juruá microbasin, located in the municipality of Guajará, State of Amazonas, Brazil (Fig. 1).

\section{Sampling}

Fish sampling was performed using $80 \mathrm{~m}$ long and three $\mathrm{m}$ high gillnets, with mesh sizes of one and a half $\mathrm{cm}$, two and a half $\mathrm{cm}$, three and a half $\mathrm{cm}$, and five and a half $\mathrm{cm}$ between opposite nodes. We used two nets, each with $12 \mathrm{~mm}$ mesh, two meters high, and 12 meters open. The nets were launched ten times at each collection point. We also used beach trawls of nine meters long and two meters and forty centimeters high, with a $13 \mathrm{~mm}$ mesh. The fish collected were sent to the Aquatic Ecology Laboratory of the Federal University of Acre-UFAC, where they were identified, measured, and weighed.

The specimens collected were anesthetized using menthol in a similar way to benzocaine. Then, to assess the presence of hemoparasites, blood samples were collected by cardiac puncture, using a hypodermic syringe containing an anticoagulant (5\% EDTA). Thus, duplicate blood smears were made per fish sample. The blood smears were stained using Quick Panoptic/LABORCLIN $\circledast$ and examined by optical microscopy with 400 and 1000x magnification, at the Microscopy Laboratory I, at the Federal University of Acre (UFAC), Campus Cruzeiro do Sul, Acre, Brazil.

The description of the trypanosomes was made with 14 specimens of Morphotype A and 11 specimens of Morphotype B. For the morphometric evaluation, the parasites were photographed using a Leica DM 500 optical microscope, with an ICC50 HD coupled camera. The photos were used to determine the morphometric characteristics of the trypanosomatids, using the ImageJ software. Cytomorphometric measurements of the trypanosomatids were performed according to Borges (2016) (Fig. 2).

\section{Data analysis}

Prevalence, mean abundance and mean intensity were calculated according to Bush et al. (1997). We used the direct method, adapted from De Carli (2001), to estimate the infection intensity (expressed in parasites $/ \mathrm{mL}$ ). We recorded and calculated all parasites found in 100 microscopic fields, with 1000x magnification. It is estimated that 100 microscopic fields are equivalent to $0.2 \mu \mathrm{L}$ of blood. Thus, the intensity of infection $=($ number of parasites $\times 5) \times 1,000=($ parasites $/ \mathrm{mL})($ De Souza and Corrêa 2019). 
The morphometric variables of Trypanosoma spp. underwent homoscedasticity (Levene) and normality (Shapiro-Wilk) tests. Thus, we used the Student's T-Test $(p<0.05)$ for the parametric data to verify a difference in the morphometric parameters between the morphotypes of Trypanosoma spp. The analyses were performed using the $\mathrm{R}$ software version 3.6.1.

\section{Results}

We collected five $P$. armatulus individuals (length $\overline{\mathrm{x}}=9.3 \pm 1.25$; weight $\overline{\mathrm{x}}=4.15 \pm 10.4$ ), all infected by Trypanosoma spp. Morphotype A $(n=14)$ was identified infecting three individuals of $P$. armatulus and Morphotype $B(n=11)$ only two, with the intensity of Trypanosoma infection in the specimens averaging $25.10^{3}$ parasites $/ \mathrm{mL}$ of blood.

The prevalence of Morphotype A in the specimens was $60 \%$, with a mean abundance of 2.8 , and a mean infection intensity of 4.6 . Morphotype B had a prevalence of $40 \%$, with a mean abundance of 2.2 , and a mean infection intensity of 5.5 in fish specimens.

The morphometric parameters of Morphotypes A (Fig. 3A) and B (Fig. 3B) of Trypanosoma spp. trypomastigotes are available in Table 1. 
Table 1

Morphometric parameters of Morphotypes A and B, expressed as mean and standard deviation ( $\mu \mathrm{m})$.

\section{Morphometric parameters}

Total body length (CT)

Body length (CC)

Nucleus length $(\mathrm{CN})$

Kinetoplast length (CK) (CK)

Free flagellum length $(F)$

Body width (LC)

Nucleus width (LN)

Kinetoplast width (LK)

Distance from the posterior end to the kinetoplast center (PK)

Distance from the kinetoplast center to the nucleus center (NK)

Distance from the anterior end to the nucleus center (NA)

Distance from the posterior end to the nucleus center (PN)
Morphotype

A

$55.6 \pm 1.5$

$37.0 \pm 1.3$

$2.8 \pm 0.2$

$0.9 \pm 0.1$

$18.5 \pm 0.9$

$2.1 \pm 0.1$

$1.5 \pm 0.1$

$0.7 \pm 0.07$

$1.1 \pm 0.1$

$22.1 \pm 1.2$

$13.7 \pm 1.5$

$14.8 \pm 1.1$

1.12

0.29

$23.3 \pm 2.2$

$24.0 \pm 1.2$

0.69

0.53

${ }^{\star} p>0.05 ;{ }^{* \star} p>0.01$

The morphometric measurements with statistical differences $(p<0.05)$ between the two morphotypes were the total length $(t=4.12 ; p=0.004)$, flagellum size $(t=2.48 ; p=0.04)$, and body length $(t=2.30 ; p=$ $0.04)$.

Trypanosoma spp. (Morphotype A).

Their body was attenuated, slender, forming undulations in the anterior part and another close to the nucleus. This morphotype showed 11 cytoplasmic vacuoles, six in the anterior part, five in the posterior part to the nucleus, and one close to the kinetoplast. The kinetoplast and the nucleus had an ovoid shape, and the Trypanosoma spp. plasma membrane was quite wavy and defined, medium flagellum, and with few flexions.

Trypanosoma spp. (Morfotipo B). 
These specimens had a slender body, with undulations, one more accentuated in the nucleus region, and four cytoplasmic vacuoles, two in the anterior and posterior part to the nucleus. These specimens had ovoid nucleus and kinetoplast, a plasma membrane wavy in the anterior and posterior part of the body. The flagellum was short with a ripple.

\section{Discussion}

The present study showed the first report of Trypanosoma spp. in P. armatulus, increasing the number of hosts for these hemoparasites. In the Amazon region, most host fish reported are from the family Loricariidae (Fujimoto et al. 2013; Corrêa et al. 2016; Souza and Corrêa; 2019). For the family Doradidae, the only species with these hemoparasites was Pterodoras granulosus, in the Tocantins River (Lopes et al. 1991). Thus, there may be more Doradidae species infected by these parasites in the region. The presence of this organism in $P$. armatulus possibly indicates the occurrence of an intermediate host, being leeches in these systems. Although we did not find leeches in fish, these infections by Trypanosoma spp. suggest the existence of these hosts in this natural environment (Lemos et al. 2015; Molina et al. 2016; Woo and Black 1984).

The prevalence of parasites in the blood of hosts was $100 \%$. This fact may be associated with this fish species behavior since they are usually found in rivers (Britski et al. 1981) and feed on organisms hidden in these environments (Sterba 1963). In this sense, there is a chance that these organisms become susceptible to attack by leeches contaminated by Trypanosoma spp. that live in these environments of margin and aquatic vegetation (Woo, 2006; Ahmed et al. 2011). In this way, identifying new hosts of Trypanosoma spp. is vital since it can assist in resolving common problems in the study of pathogens caused by these parasites, in addition to contributing to the phylogeny of the trypanosomatid group (Lom 1979).

The present study showed two trypomastigote morphotypes of Trypanosoma spp. in P. armatulus, with a higher prevalence of Morphotype A. However, we did not find both morphotypes were in the same individual. Some authors consider that the same fish species may be infected by more than one Trypanosoma species (Fróes et al. 1979; Ribeiro et al. 1990; Lemos et al. 2015). Thus, there is no specificity of this hemoparasite with a host. However, Trypanosoma spp. showed high pleomorphism (Eiras et al. 2012). Therefore, it is impossible to determine that Morphotypes A and B found here represent different species since the measurements with significant differences may suffer variations during the parasite development in the host. According to Lom (1979), pleomorphism can be expressed in aspects such as changes in the body's total length and width (thin or wide shapes) and the free flagellum length. The number of undulations in the undulating membrane, the presence and number of cytoplasmic granules, and the distance from the posterior kinetoplast are also aspects expressed by pleomorphism. It was mainly these morphological characteristics that varied in Morphotypes A and B.

We found, for the first time, Trypanosoma spp. infecting $P$. armatulus, increasing the number of hosts for these trypanosomatids. This study also suggests that different forms of these hemoparasites can occur 
in the same fish species. We emphasize that the material collected in this study is stored, and future molecular analyses will be carried out, including the genetic material sequencing, which will confirm whether these differences are pleomorphism or are related to different Trypanosoma species.

\section{Declarations}

\section{Author Contributions Statement}

For the preparation of this short communication, for analysis and illustrations of the following work were done by Gabriele Oliveira Texeira and Henrique Paulo Silva de Melo for intellectual part and corrections Sérgio Luis Prolo, Ricardo Massato Takemoto, Luís Marcelo Aranha Camargo e Dionatas Ulisses Meneguetti

\section{References}

1. Albuquerque CMR, PJ Ham (1996) Efeito in vivo de uma defensina natural do Aedes aegypti no desenvolvimento de Brugia pahangi. Entomologia médica e veterinária. 10.4: 397-399.

2. Borges AR (2016) Estudo morfológico e biológico de tripanossomas de peixes no Brasil: caracterização in vivo e in vitro [Dissertação]. Rio de Janeiro: Universidade Federal de Juíz de Fora.

3. Britski HA (1981) Sobre um Novo Gênero e Espécie de Sorubiminae da Amazônia (Peixes, Siluriformes). Papéis Avulsos de Zoologia, 1981; 34 (7): 109-114.

4. Bush AO, Lafferty, KD, Lotz J.M, Shostak W (1997) Parasitology meets ecology on its own terms: Margolis et al. Journal of Parasitology, 83: 575-583.

5. Eiras JC, Rego AA, Pavanelli GC (1990) Trypanosoma nupelianus sp. n (Protozoa, Kinetoplastida) parasitizing Rhinelepis aspera (Osteichthyes, Loricariidae) from Paraná river, Brazil. Mem Inst Oswaldo Cruz. 85(2): 183-184.

6. De Carli GA (2001) Parasitologia Clínica: Seleção de Métodos e Técnicas de Laboratório para o Diagnóstico das Parasitoses Humanas. Editora Atheneu, São Paulo.

7. De Souza DC, LL Corrêa (2019) A comparative study of Trypanosoma sp. (Protozoa: Kinetoplastida) parasitizing four species of loricarides in the Brazilian Amazon. Biologia. 74.9: 1163-1170.

8. Eiras JC (1994) Elementos de Ictioparasitologia. Porto: Edições Afrontamento.

9. Eiras JC, Segner H, Wahli T, Kapoor BG (2008) Fish Diseases. Enfield: Science Publishers. vol. 1.

10. Eiras, JC, Takemoto, RM, Pavanelli, GC, Luque JL (2012) Checklist of protozoan parasites of fishes from Brazil. Zootaxa. 3221: 1-25.

11. Fonseca F, Vaz Z (1928) Novos trypanosomas de peixes brasileiros. An Facul Med SP. 3: 69-94

12. Froés OM, Fortes E, Lima DF, Leite VRV (1979) Tripanossomas (Protozoa, Kinetoplastida) de peixes de água doce do Brasil. II: Novos tripanossomas de cascudos (Pisces, Loricariidae). Rev Bras Biol. 39: 425-429. 
13. Fujimoto RY, Neves MS, Santos RFB et al (2013) Morphological and hematological studies of Trypanosoma spp. infecting ornamental armored catfish from Guamá River-PA, Brazil. Anais Acad. Bras. Cienc. v.85, p.1149-1156.

14. Lemos M, Fermino BR, Simas-Rodrigues C, Hoffmann L, Silva R, Camargo EP, et al (2015) Phylogenetic and morphological characterization of trypanosomes from Brazilian armoured catfishes and leeches reveal high species diversity, mixed infections and new fish trypanosome species. Parasit Vectors 8(1): 573.

15. Lom J, Dykova I (1992) Protozoan parasites of fish. In: Lom J, Dykova I. Developments in aquaculture and fisheries science. Amsterdam: Elsevier vol. 26.

16. Lom J (1979) Biology of Trypanosomes and Trypanoplasms of fish. In: Lumsden WHR. Biology of Kinetoplastidae. London: Academic Press p. 269-337, vol. 2.

17. Meneguetti DUO, Soares EB, Campaner M, Camargo LMA (2014) First report of Rhodnius montenegrensis (Hemiptera: Reduviidae: Triatominae) infection by Trypanosoma rangeli. Rev. Soc. Bras. Med. Trop. [online] vol.47, n.3, pp.374-376.

18. Molina, JP et al (2016) Tripanossomatídeos (Protozoa: Kinetoplastida) em três espécies de cascudos do rio Mogi-Guaçu, Pirassununga, São Paulo, Brasil. Rev. Bras. Parasitol. Vet. [online] vol.25, n.2, pp.131-141. Epub June 07, 2016. ISSN 1984-2961.

19. Molyneux D, Ashford R (1983) A Biologia do Trypanosoma e Leishmania, Parasitas do Homem e Animais Domésticos. Taylor e Francis, Londres.

20. Ribeiro RD, Lopes RA, SatakeT, Nuti A So, Britski HA (1990) Trypanosomes of brazilian fishes. IX. Trypanosoma pintoi sp. n. from armored catfish Hypostomus sp. (Pisces, Loricariidae), from MogiGuaçu river, municipality of Pitangueiras, SP, Brazil. Rev Bras Biol 50: 559-562.

21. Roubach R, Gomes LC, Val AL (2001) Safest level of tricaine methanosulfanate (MSS-222) to induce anesthesia in juveniles of matrinxã (Brycon cephalus). Acta Amazonica, 31:159-163.

22. Sterba G (1963) Freshwater Fishes of the World. New York, Viking Press.

23. Woo PTK, GA Black (1984) Trypanosoma danilewskyi: host specificity and host's effect on morfometrics. The Journal of parasitology 1 788-793.

\section{Figures}



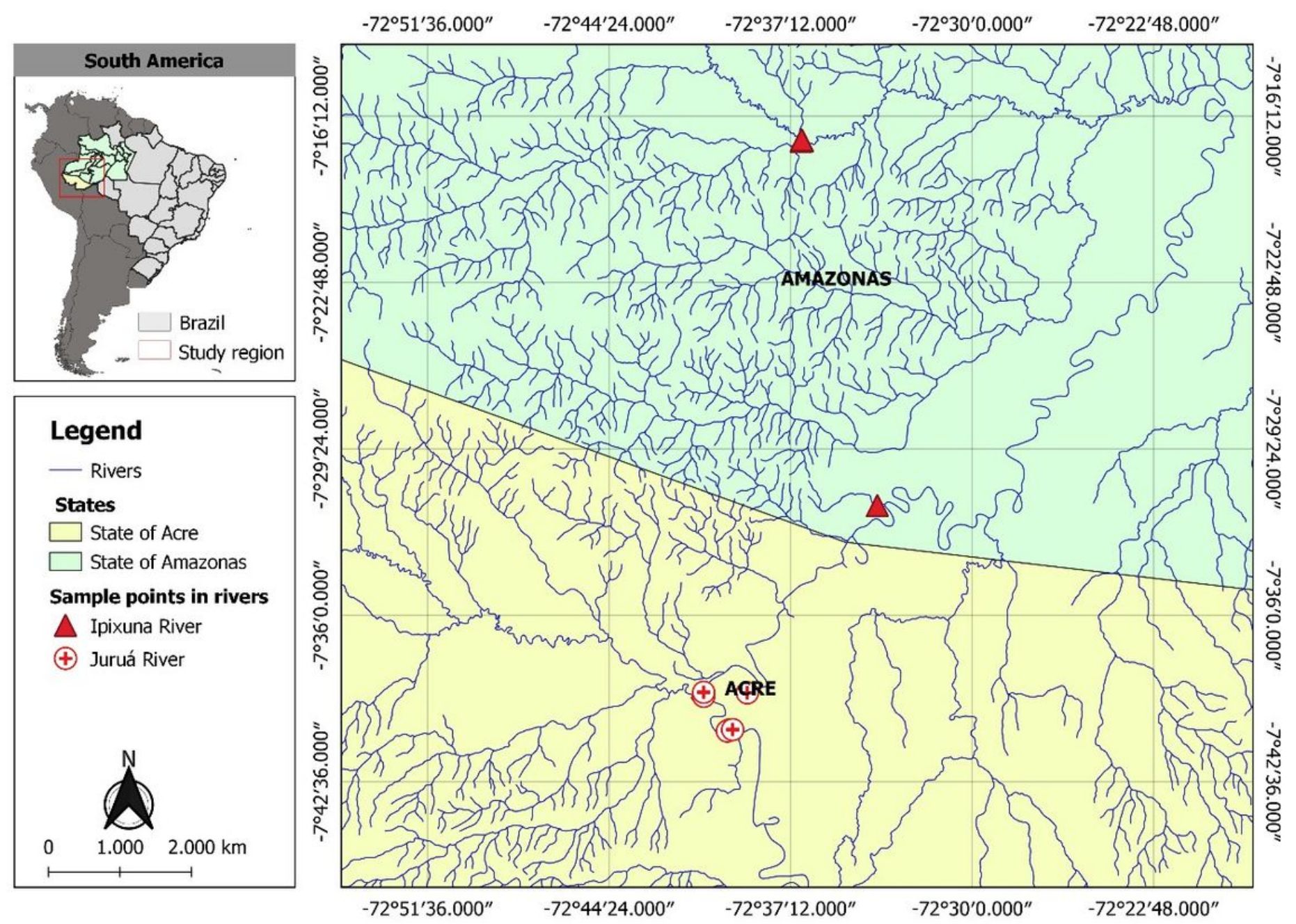

Figure 1

Location and georeferencing of river where P. armatulus samples were collected. Note: The designations employed and the presentation of the material on this map do not imply the expression of any opinion whatsoever on the part of Research Square concerning the legal status of any country, territory, city or area or of its authorities, or concerning the delimitation of its frontiers or boundaries. This map has been provided by the authors. 


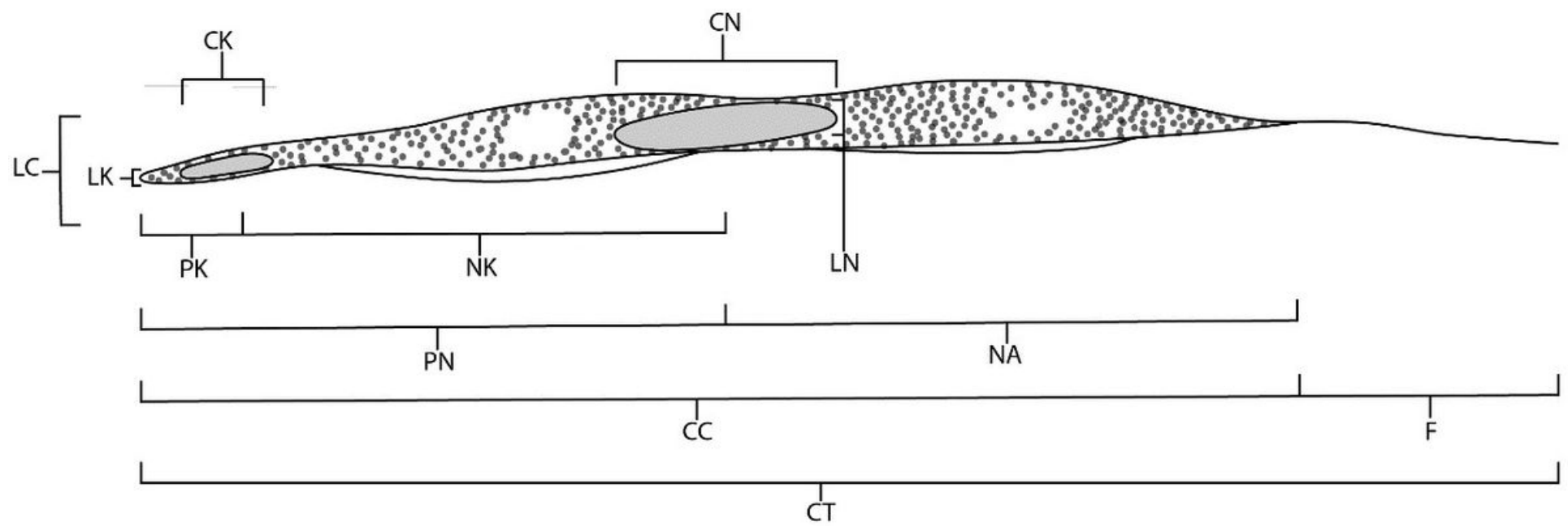

\section{Figure 2}

Scheme of the morphometric measurements of trypanosomatids found in P. armatulus. Total body length (CT); Body length (CC); Nucleus length (CN); Kinetoplast length (CK); Free flagellum length (F); Body width (LC); Nucleus width (LN); Kinetoplast width (LK); Distance from the posterior end to the kinetoplast center (PK); Distance from kinetoplast center to the nucleus center (NK); Distance from the anterior end to the nucleus center (NA); Distance from the posterior end to the nucleus center (PN). 

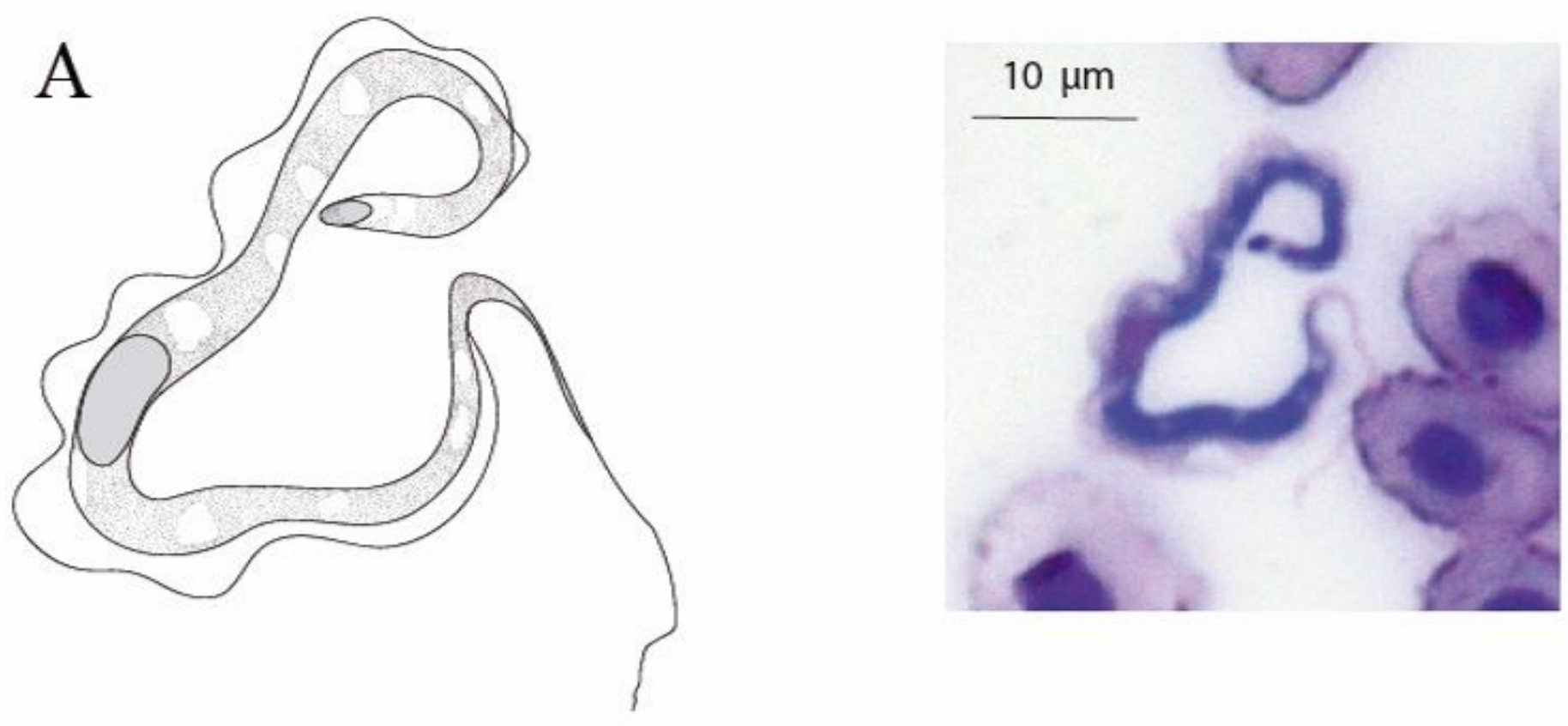

B
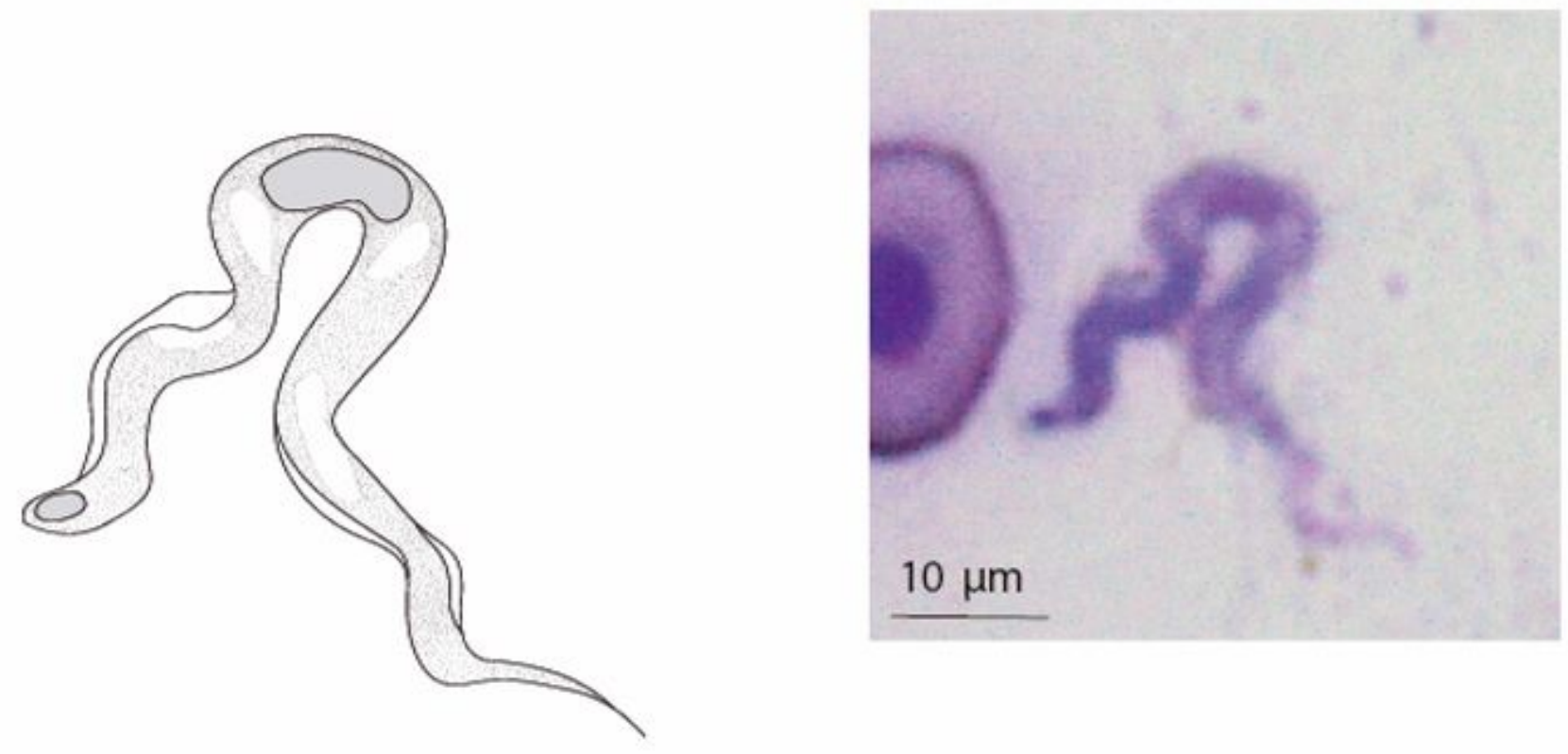

\section{Figure 3}

Morphotypes of the trypomastigote forms of Trypanosoma spp. found parasitizing P. armatulus in the Juruá River basin system. A - Morphotype A; B - Morphotype B (scale = $10 \mu \mathrm{m})$. 